Удк 351

A. C. Мартишин, к. н. з богосл., завідувач кафедри украӥнознавства, православ' я та теологї, Міжрегіональна академія управління персоналом, м. Київ

DOI: $10.32702 / 2306-6814.2018 .20 .94$

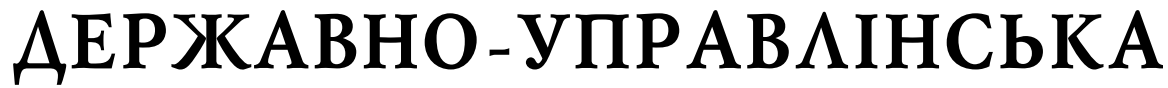

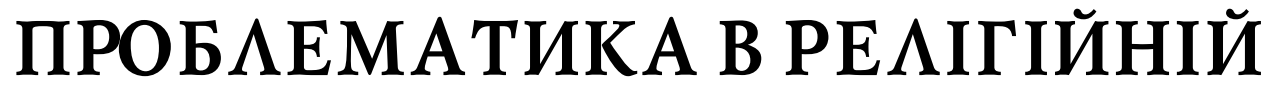 ФI $\Lambda$ ОСОФIÏ XX СТО ITТЯ
}

\author{
D. Martyshyn, \\ candidate sciences in theology, head of the Department of Ukrainian Studies, \\ Orthodoxy and Theology, Interregional Academy of Personnel Management, Kyiv
}

\section{STATE MANAGEMENT ISSUES IN THE RELIGIOUS PHILOSOPHY OF THE XX CENTURY}

У статті розглядаються питання природи духовності людської особистості, розвитку держави, релігії, етики, політики та Церкви у духовній спадщині російських релігійних мислителів XX століття. Проаналізовано основні етапи розвитку філософської та соціальної думки релігійної філософії з урахуванням специфіки та зв 'язку духовного знання людства з державним управлінням. Основну увагу приділено тим мислителям, які обстоювали загальнолюдські духовні цінності, творчості, свободи у контексті взаємодії релігії, політики та ідеології.

На думку російських релігійних філософів ХХ століття, звернення науковців до християнства, віровчення та духовного досвіду Церкви допомагає формуванню нових інноваційних підходів до державного управління. Церква, проповідуючи християнські цінності, стверджуючи духовні ідеали, просвічуючи суспільство світлом християнського віровчення, формує громадськудумку та певне просвічене ставлення соціуму до держави, політики. Одухотворене суспільство, яке живе вічними, а не тимчасовими, скороминущими цінностями, являє собою найбільш істотну характеристику розвиненої держави й демократичного громадянського суспільства. Релігійна позиція відповідальності людини перед Богом не дозволяє людині залишатися байдужою до викликів сучасної глобалізації.

Кризові явища в політичному, економічномута соціальному житті суспільства вимагають концентрації зусиль не лише держави, але й релігійних, громадських організацій. Згідно з вченням релігійних філософів XX ст. , всі багатогранні напрями діяльності релігійних організацій спрямовані не на досягнення політичних та економічних цілей, а на досягнення головної мети: благодатного преображення, очищення світу, яке здійснюється в історії людства в творчій синергії людини й Бога. Виходячи з цієї великої мети, паралельно стверджуючи християнські принципи буття, Церква формує міцну державу, розвинуте громадянське суспільство, створює духовні умови вільного розвитку людської особистості, духовного та морального добробуту соціуму. В історії людства християнство завжди виступало захисником свободи волі та гідності людини. Релігійні мислителі саме у світлі християнської істини осмислювали становлення та розвиток держави, багатогранні процеси політики, економіки, соціальні та духовні інтереси людства. В умовах глобальних криз XXI ст. творчий спадок релігійних філософів стає досить запитаним сучасною наукою.

The article deals with the issues of the nature of the spiritual personality of the human person, the development of the state, religion, ethics, politics and the Church in the spiritual heritage of Russian religious thinkers of the XX century. The basic stages of development of philosophical and social thought of religious philosophy are analyzed with account of specificity and connection of spiritual knowledge of humanity with state administration. The main attention is paid to those thinkers who advocated universal human values, creativity, freedom in the context of the interaction of religion, 
politics and ideology. The features of state-management processes in the context of the relationship between the state and Christianity are investigated and the need to apply the synthesis of religion and science is proved.

According to Russian religious philosophers of the XX century, the appealof scholars to Christianity, doctrine and spiritual experience of the Church helps to form new, innovative approaches to state governance. The church, preaching Christian values, affirming spiritual ideals, enlightening society with the light of Christian doctrine, forms public opinion and a certain translucent attitude of society to the state and politics. The spiritualized society, which lives eternally, and not temporary, passing values, is the most significant characteristic of a developed state and a democratic civil society. The religious position of human responsibility before God does not allow a person to remain indifferent to the challenges of modern globalization.

Crisis phenomena in the political, economic and social life of society require the concentration of efforts not only of the state, but also of religious, public organizations. According to the teachings of the religious philosophers of the XX century, all the multifaceted directions of the activities of religious organizations are aimed not at achieving political and economic goals, but in achieving the main goal: the graceful transformation, the purification of the world, which is carried out in the history of mankind in the creative synergy of man and God. Proceeding from this great goal, in parallel with the Christian principles of being, the Church forms a strong state, developed a civil society, creates spiritual conditions for the free development of the human person, spiritual and moral well-being of society. In the history of mankind, Christianity has always been the advocate of freedom of the will and dignity of man. Religious thinkers, in the light of Christian truth, comprehended the formation and development of the state, the multifaceted processes of politics, economics, social and spiritual interests of mankind. In the context of the global crises of the XXI century, the creative heritage of religious philosophers becomes quite demanded by modern science.

Ключові слова: держаВа, християнство, релігія, релігійна фрілософрія, сочіальна думка, наука, фрілософоя, політика, етика, мораль, духовність, творчість, економіка, духовно-релігійна сфера.

Key words: state, christianity, religion, religious philosophy, social thought, science, philosophy, politics, ethics, morality, spirituality, creativity, economics, spiritual and religious sphere.

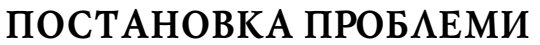

У сучасній християнській богословській науці йде складний та багатогранний процес народження нових соціальних сенсів життєвих орієнтирів соціуму, вкорінених не лише в Святому Письмі (Біблії), багатовекторній релігійній традиції світу, творах святих отців, але й у релігійній фрілософрії і у сучасній науці. В цих умовах і виникає необхідність звернення світських та церковних науковців, які займаються питаннями та проблемами розвитку державного управління, до релігійно-фрілософрського спадку релігійних фрілосоорів XX ст.

Слід мати на увазі, що державно-управлінська проблематика, питання становлення та розвитку соціального вчення християнства у контексті державного управління посідають особливе місце в структурі наукового знання та у практиці духовного життя сучасної людини. Звертаючись до релігійної фрілософії, дослідники мають унікальну можливість аналізувати релігійні, державницькі, соціальні, етичні та політичні питання у спадку релігійних мислителів та фрілософрів.

Зазначимо, що наше дослідження присвячене ролі релігійної фрілософії у вивченні питань державно-управлінської проблематики, в аналізі особливостей релігій- но-фрілософрського розуміння соціальних проблем розвитку держави, життя суспільства, виробленого в російській релігійно-філософській думці, та визначеннюїї співвідношення з рефлексією сучасних дослідників у галузі державного управління. Проблема державного управління вперше як наукова проблема підіймається в російській фрілософії та одержує своє продовження на всіх подальших етапах становлення й розвитку соціальної думки християнства. В релігійній фрілософрії XIX початку XX ст. питання впливу релігії на соціум видавалося актуальним для таких релігійних мислителів, як: К.Н. Леонтьєв, Л.О. Тихомиров, В.С. Соловйов, С.Н. Булгаков [7-11], М.О. Лосський [19], В.В. Розанов, М.О. Бердяєв [1-6], С.Л. Франк [27-30]. Дослідження питань взаємодії держави та Православної Церкви, священнослужителів та світських науковців було в значному ступені основою конструктивного діалогу держави, інтелігенції, суспільства та Церкви в дореволюційній Pociï [12-14; 18; 24].

Відомо, що у фундаментальних працях російських фрілософрів відображені загальнолюдські проблеми, соціальні та духовні вектори розвитку людства. Зважаючи на важливість осмислення викликів сучасної цивілізації, 
необхідно звернутися до філософського спадку найбільш яскравих представників релігійної фрілософії, який відображує релігійну, історичну своєрідність релігійної думки та специфіку духовно-історичного та соціально-політичного розвитку суспільства $\mathrm{XX}$ ст.

Важливо зазначити, що в практичному плані, увага до проблеми становлення й розвитку держави безпосередньо пов'язана із духовною, соціальною, економічною та політичною ситуацією в сучасному світі, з наростаючими процесами глобальної кризи етики, економіки, фінансів та культури, вибору сучасною людиною шляху, що веде до модернізації і одночасного духовно-морального оновлення. Відмова певної частини сучасного суспільства, в тому числі Європи, від християнських цінностей, зневажливе ставлення до теологічної й релігійно-фрілософської думки, питань моралі, духовності, забуття справ милосердя, любові, прощення й духовних чеснот веде сучасну цивілізацію до руйнування й духовної загибелі.

Звернення до релігійної фрілософрії, вивчення соціальної проблематики у спадку російських фрілософів XX ст., у цьому контексті, набуває особливої значущості, як для фрілософії, богослов'я, так і для державного управління. За словами одного з теоретиків українського релігієзнавства, професора Л. Филипович, "найбільше проблем у відносинах християнських Церков і держави виникає там, де представники влади є найменш нейтральними і світськими людьми. Очевиднимє те, що державний службовець не має права виявляти свої власні вірування або демонструвати належність до якоїсь Церкви. До всіх релігій він має ставитися однаково, знаходитися на однаковій відставні від різних Церков. Однак, це не означає, що керувати державою мають лише люди невіруючі. Світськість службовця передбачає не відсутність віри у держслужбовця, а невикористання своїх власних конфесійних уподобань на державній службі. Про те світськість у нас ще й досі часто хибно ототожнюють із безвір'ям" [26, с. 414-415].

У науковому плані, постанова проблеми та спроба іiї осмислення з позицій державного управління видаються актуальними у зв'язку з тим, що наявні на сьогоднішній момент фрілософські дослідження державноуправлінської думки російських фрілософрів носять значною мірою ознайомлювальний та суто етично-моральний характер. Попри свою значущість і неминущу цінність для фрілософської та богословської науки, праці релігійних фрілософрів не можуть відображати всіх боків фрілософії державного управління.

\section{АНА ІІЗ ОСТАНHIX АОС $А$ АЖЕНЬ І ПУБАІКАЦІЙ}

Помітний внесок у вивчення фрілософії та соціальної думки російських релігійних фрілософрів зробив цілий авторський колектив українських учених під науковою редакцією профресора, доктора фрілософських наук, академіка Національної академії наук України Л.В. Губерського. Бібліографрічний словник "Філософрська думка східних слов'ян" [22] дозволяє об'ємно та масштабно ознайомитися з духовною культурою та фрілософрією XIX - XX ст. Про богослов'я, соціальну думку та фрілософрьку творчість представників релігійної фрілософрії писали такі релігійні фрілософри й богослови російської еміграції, як протоієрей Г.В. Флоровський та протоієрей В.В. Зеньковський Особливо слід відзначити фундаментальне дослідження "Історія російської філософії" [15] протоієрея Василя Зеньковського. Встановлено також, що дослідженню аспектів релігійнофілософської та соціальної думки великих російських фрілософрів присвячено значну кількість праць іноземних дослідників. Назвемо імена таких авторів, як М. Лосський [19], Т. Шпидлик [31], О. Замалєєв [14], В. Бичков [12], Л. Новікова, И. Сиземська [21], К. Воденко [13], К. Костюк [18]. Осмисленню політичних, релігійних й соціологічних поглядів релігійних мислителів присвячені численні праці професора В.Ю. Катасонова [16; 17]. Зазначимо, що В.Ю. Катасонов вперше вводить у науковий обіг соціальну етику релігійних філософів як відносно самостійну галузь досліджень. її відмінна особливість полягає в переважній спрямованості не стільки на соціальне пізнання та економічну емпірику, скільки на духовний вимір політики, розвитку держави, економіки та соціальних проблем суспільства.

У книзі відомого церковного історика, професора, протоієрея Георгія Митрофранова "Росія XX століття "Схід Ксеркса" чи "Схід Христа"" [20] надано не лише основні віхи життя визначних релігійних фрілософрів, але й історико-фрілософський аналіз творчості представників російської релігійної думки. До числа релігійних мислителів із певністю можна віднести протоієрея Сергія Булгакова, М.О. Бердяєва, І.О. Ільїна та С.Л. Франка.

\section{ФОРМУ ЮЮВАННЯ ЦІАЕЙ СТАТТІ (ПОСТАНОВКА ЗАВААННЯ)}

Метою статті $є$ розкриття основних ідей державноуправлінських рішень видатних російських релігійних мислителів XX ст.

Мета дослідження зумовила постановку і розв' язання таких завдань:

- проаналізувати історію і динаміку розвитку релігійно-фрілософських поглядів мислителів на державу, релігію, людину та суспільство;

- систематизувати предметне поле дослідження, визначити основні категорії та теоретичні поняття, що застосовуються фрілософами в процесі аналізу процесів державотворення;

- інтегрувати християнські погляди релігійних фрілософів у сореру теоретичних питань сучасного державотворення і державного управління;

- розкрити особливостібогословської методології та окреслити головні уявлення про цілісну методологію соціального вчення Церкви;

- дослідити прийоми і методи цілісної методології у дискурсі державотворення та релігійної фрілософії;

- визначити теологічні підстави для діалогу держави та Церкви в творчій спадщині релігійних мислителів XX ст.

\section{ВИК ААА ОСНОВНОГО МАТЕРІААУ}

Враховуючи вищевикладене, доцільно сказати про те, що відомі російські фрілософри XX ст. не ставили перед собою завдання створення соціального вчення християнства, концепції державного управління, вони спеціально не займалися написанням навчальних посібників 
та наукових монографрій, присвячених державному управлінню й соціальній доктрині християнства. Але у своїх фундаментальних працях релігійні фрілософи тою чи іншою мірою торкалися проблем політики, держави, соціальної думки християнства, історії, права, економіки, релігійної етики, соціальної стратифрікації, родини, шлюбу, а також і багатьох інших сторін суспільного життя. Таким чином, у фрілософрських, політологічних, соціологічних дослідженнях, книгах, статтях російських філософів можна відшукати чимало важливих спостережень, фрілософських роздумів щодо державно-управлінської проблематики, висновків та зауважень, що мають прямий або опосередкований стосунок до сфери державного управління.

Таким чином, державно-управлінська думка представників російської релігійної фрілософії вирізняється складністю, глибокою й тонкою розробленістю фрілософської проблематики та релігійної концепції, яка охоплює проблеми Бога та світобудови, світу й людини, суспільства та Церкви, містики та наукового пізнання, політики та культури. Багато в чому їхні ідеї $є$ унікальними, оригінальними, неповторними, але вони вбирають у себе найбільш важливі досягнення світової фрілософії, соціології, релігієзнавства та людської історії. Їхні праці стали вельми плідними для розвитку сучасної науки, багато їхніх висновків та передбачень про революцію, духовну кризу людства та війну підтверджено самим життям.

Зазначимо, що фрілософські підходи, моделі, історичні парадигми релігійних мислителів у вивченні суспільства, релігії, фрілософії містять певні важливі богословські та фрілософрські інтуїції, які дозволяють сучасному вченому розгортати дослідницьке поле та розвивати богословську рефлексію.

Наріжним каменем фрілософрської ідеї релігійних фрілософрів було розуміння того, що політика, економіка, соціальні зацікавлення суспільства мають підкорятися духовно-релігійній сорері життя людини. Таке розуміння ролі та місця релігії в суспільстві цілком вписується в соціальне вчення християнства. Для ілюстрації розуміння релігійними мислителями місця релігії в суспільстві наведемо низку цитат С.Л. Франка: ""Бог $є$ основою людського життя, його живленням" [29, с. 94]. "Бог є вічною твердинею, вічним життям, абсолютним благом та всеохопним світлом розуму" [29, с. 54]. "Ми страждаємо не від надміру, а від нестачі духовної сили. Ми знемагаємо в пустелі, душа наша шукає не безглуздого простору відчуженості від усього, а, навпаки, щільного, остаточного злиття з чимось невідомим, що може раз назавжди заповнити, зміцнити, наситити ії" [28, с. 163].

Зазначимо, що духовний досвід релігійних мислителів доводив їм, що іншого виходу з глобальної політичної, чи економічної кризи не існує, крім прямого звернення сучасної людини до Бога. Цікаво, що ідея домінування релігії над економікою та політикою посідає визначне становище в історії не лише в російській релігійної фрілософрії, але й у культурологічних підходах Європи та США.

Досліджуючи питання державно-управлінської проблематики у думці релігійних фрілософрів XX ст., необхідно, в першу чергу, проаналізувати низку питань, що залишилися невирішеними в цілій низці праць із християнської апологетики, соціальної фрілософії, соціології та політології. Це, передусім, питання становлення й розвитку соціальної науки Церкви. Виклики сучасного світу, глобальні трансформації політики, економіки та соціальної сфери життя сучасного суспільства стають об'єктом вивчення не лише світської науки, але й соціальної думки християнства. Згідно з християнською теологією, складна система християнського соціального знання $€$ не лише найважливішим, ключовим напрямком облаштування церковного життя на парафії, але й найважливішим вектором розвитку всього соціуму.

Зрозуміло, що саме тому молода богословська наука "Соціальне вчення Церкви", яка, ще сама перебуваючи в стадії розвитку, всебічно залучає у свій науковий арсенал наукові праці з державного управління, політології, соціології, соціальної фрілософії, осмислюючи основи становлення й розвитку держави, суспільства і людини через призму християнської теології. Соціальне вчення Церкви, вивчаючи соціальні явища життя через призму теології, доносить до свідомості сучасної людини не лише цінності християнства, але й розкриває неоцінений потенціал сучасної науки.

Отже, цілком законним буде таке формулювання: соціальне вчення Церкви $є$ невід'ємною частиною християнського віровчення, яке звернене до сучасного суспільства з метою пояснення соціальних процесів буття та вирішення глобальних проблем соціуму в світлі Святого Письма, Священного Передання Церкви й сучасної світської науки. Іншими словами, це погляд Церкви на сучасне суспільство у світлі наукового пошуку істини. Іншими словами, богословський погляд, який випливає з глибинних основ християнської віри та християнського вчення про Бога, Церкву, людину та суспільство.

Зрозуміло, що спадок релігійної фрілософії дозволяє системно викласти низку певних питань у діалозі державного управління та християнської науки. Вивчення творчості релігійних мислителів передбачає осмислення духовного та соціального буття людства, основних аспектів політології, державотворення та проблем розвитку суспільства, а також найважливіших аспектів релігійної культури, науки та фрілософії, пов'язаних із соціальними явищами в історії людства.

Наголосимо, що соціальна поведінка людини, політика та економіка стосуються безпосередньо діяльності людини та суспільства, але їі, згідно до основних ідей російських релігійних фрілософрів, не можна зводити лише до матеріального детермінізму та примату матерії над духом. Соціальний чинник знаходить вияв у всіх аспектах людського буття, але найголовнішим для думки орілософрів $\epsilon$ те, що він відображує та реалізує духовну сутність людини, її духовні прагнення та ідеали.

Враховуючи вищевикладене, доцільно сказати про те, що російська релігійна фрілософрія $X X$ ст. була представлена сукупністю різних богословських теорій, філософських течій, політичних поглядів, але вона підіймала найважливіші питання життя держави, людини та суспільства, які не втратили своєї актуальності й сьогодні при вивченні основ становлення й розвитку науки "державне управління". 
Складне фрілософське та соціологічне питання про те, що таке держава, суспільство, є питанням великої ваги і для релігійної фрілософії. Існують історичні, політологічні, економічні та інші відповіді на це питання. Вивченням держави та суспільства займаються різні напрями сучасного знання: державне управління, соціологія, політологія, право, соціальна фрілософія. 3 погляду православного віровчення інтегральна роль у вивченні соціуму належить еклесіології (вчення про Церкву), соціальному вченню Церкви, антропології та християнській апологетиці. Всі богословські науки роблять свій вагомий внесок у формування загальних уявлень про людину та суспільство.

Представники російської релігійної фрілософрії, які займалися вивченням держави й суспільства, обрали дослідницький шлях, на якому розглядаються питання фрормування та розвитку держави і соціуму в контексті релігійної та духовної культури. Чи треба говорити про те, що в основі соціальних зв'язків людей лежать цінності релігії, культури та моралі. Ще слов'янофіли заклали основи фрілософрії "цілісного духу", "цілісного знання", яке й дістало назву російської релігійної фрілософрії. Аж ніяк не заперечуючи наявності в нашій історії змістовної світської фрілософської думки, в тому числі й атеїстичної, ми все ж гадаємо, що найбільш яскраво та оригінально російська думка проявила себе саме тоді, коли вона взяла до уваги питання існування Бога. Сутність релігійної фрілософрії полягає в гармонійному сполученні духовних та матеріальних основ буття. Концепція "цілісного знання", "сутність віруючого мислення", "цілісність духу" - всі ці фрілософрські ідеї російської релігійної фрілософрії говорять про головне, про безперервний рух людства до Бога, Який є початком і кінцем людини та всієї людської історії. На сьогоднішній день, відомо, що релігійна фрілософрія являє собою загальний термін на позначення вельми розмаїтих фрілософрських досліджень видатних мислителів, фрілософів, у яких проблема пізнання світу й людини пов'язана 3 питанням пізнання Бога.

На нашу думку, комплексний соціально-фрілософрський та богословський аналіз фрілософрії, економіки, етики, права та богослов'я релігійних мислителів дозволяє прийти до висновку про те, що визначними фрілософрами було сформовано певне соціальне знання, яке можна умовно охарактеризувати як християнську соціологію. Таким чином, проблеми взаємодії Церкви та держави $є$ одним із найбільш актуальних питань соціальної думки релігійних мислителів $\mathrm{XX}$ ст. Очевидно, що пункти дотику релігії та політики знаходяться у сорері державного управління, комунікації, в області суспільних зв'язків та стосунків між людьми, їх духовного єднання або роз'єднання, боротьби та протистояння. Якщо державну, партійну, соціальну політику не засновувати на моралі, то людство і взагалі не має майбутнього. Саме життя багатьох представників російської релігійної фрілософії дає приклади вивчення політичних ідеологій, активної участі в політичних організаціях та управлінні державою. "Дійсно, серед видатних російських релігійних фрілософів можна було знайти не лише тих, хто, подібно до М.О. Бердяєва або С.Л. Франка пройшов у своєму творчому розвитку через стадію щирого захоплення марксизмом та глибокого вивчення його теоре- тичних принципів, але й тих, хто, подібно до С.Н. Булгакова або П.Б. Струве, могли вважатися провідними в російській академічній науці спеціалістами в царині вивчення марксизму навіть після свого світоглядного розриву з марксистською ідеологією", - пише відомий історик, богослов, протоієрей Георгій Митрофранов [20, с. 13].

Підкреслимо, що при вивченні історії політичної думки, духовних основ пошуку істини інтелігенцією, основна увага дослідників буде звернена до спадку релігійних мислителів, фрілософрів: протоієрея Сергія Булгакова, М.О. Бердяєва, Б.П. Вишеславцева, І.О. Ільїна, Ф.О. Степуна, П.Б. Струве, Г.П. Федотова и С.Л. Франка. Не лише їхні книги, але й саме життя сповнене політичними захопленнями, ідеями, острахами, хворобами та перспективами побудови майбутнього.

Релігійні мислителі та фрілософи були зайняті науково-богословським та фрілософрським осмисленням природи та сутності політики, еволюції становлення й розвитку держави, тенденцій розвитку політичних ідеологій, а також вивченням багатогранних явищ суспільства. Актуальність релігійної фрілософії порівняно 3 іншими фрілософськими напрямами знання людства полягає в тому, що вона, досліджуючи державу, політику, суспільство, розглядає соціум в органічному взаємозв'язку з релігійними інститутами. Такий контекст розгляду політики $є$ завжди особливо актуальним та перспективним у науково-релігійному напрямі вивчення суспільства. Держава, влада політиків, тиранія ідеології при цьому не затуляють розуму філософра й богослова, як це властиво, наприклад, самим політикам та лідерам політичних рухів і партій.

Релігійна фрілософрія розглядає політику як явище, підкорене інтересам самого суспільства та спрямоване на становлення, розвиток соціуму, а також забезпечення можливостей творчої самореалізації людини. Релігійна думка дозволяє діагностувати духовний рівень та характер політичної ідеології, ідеї, виробляти практичні рекомендації з розширення духовної бази розвитку суспільства. Для релігійних мислителів, принципово важливо дослідження природи влади й держави з позицій християнського богослов'я.

Центральне місце в своїх політологічних концепціях релігійні мислителі відводили Церкві. Вони чудово розуміли, що держава, концентруючи більшість ресурсів, використовуючи монополію на законне насильство, володіє найбільшими можливостями впливу на людину. Але, в свою чергу, на державу та суспільство, не меншою мірою, може впливати, на їхню думку, і Церква. "Церква, - говорить Миколай Бердяєв, - може в міру своєї духовної сили зсередини впливати на життя держави та духовно спрямовувати його на шлях правди" [5, с. 721]. Усім відому думка, що покликання держави не в тому, щоби перетворити земне життя на рай, а в тому, щоби вберегти її від перетворення на пекло.

У цьому сенсі політичне життя суспільства видається більш широким поняттям, ніж "політичне управління", що включає державу, політику, цінності, ідеологію, мотивацію та побудову майбутнього соціуму. Визначні соціологи Ю.П. Сурмін та І.П. Бидзюра роздумують: "у суспільствах із тоталітарними та авторитарними політичними системами в умовах, коли вони мають, з одного 
боку, державний характер, а з іншого - компартійний, термін "політичне управління" фрактично розглядався або як політичне керівництво політичною системою 3 боку партії, або збігався з терміном "державне управління". В міру демократизації суспільство збагачує зміст влади, яка зосереджується не лише в державі, але й у недержавних організаціях як представниках громадянського суспільства; при цьому зміст терміну "політичне управління" стає багатшим та охоплює не лише державне управління та політичне керівництво але й управлінську та самоуправлінську діяльність політичного спрямування" [25, с. 387].

Російські релігійні мислителі та фрілософи вивчали не лише історію держави, права, економіку, але й релігійні ідеї, що впливали на політичну дію та керівництво. Виходячи з духовних імперативів осмислення життя, важливо сказати про відмінність природ держави та Церкви. "Маючи відмінні природи, Церква та держава вдаються до різних засобів для досягнення своїх цілей. Держава спирається в основному на матеріальну силу, включаючи силу примусу, а також на відповідні світські системи ідей. Церква ж має в своєму розпорядженні релігійно-моральні засоби для духовного керівництва пасеними та для здобуття нових чад" [23].

Зазначимо, що в сучасній політологічній та соціологічній літературі під державою зазвичай мається на увазі універсальна для суспільства країни організація, що посідає своєрідну суверенну публічну владу та спеціальний апарат для регулювання суспільних стосунків та легітимного (законного й обгрунтованого) примусу [25, с. 388].

Державає однією з базисних стійких систем соціуму, на яких засноване суспільство. Держава виникла в глибокій давнині у зв'язку з необхідністю ведення людьми "спільних справ", здійсненням розподілу праці, захистом приватної власності та регулюванням стосунків між класами, реалізацією потреби людей у порядку та захищеності й проминула в своєму розвитку величезну кількість різновидів та форм. Тому Церква навчає: "Держава як необхідний елемент життя в зіпсованому гріхом світі, де особистість і суспільство потребують огорожі від небезпечних проявів гріха, благословляється Богом" [23].

Паралельно з цим важливо сказати й про те, що Церква не допускає абсолютизації влади держави, бо суспільство об'єднує різноманітні фрорми життя, в тому числі й політичну систему, в якій держава є лише складовою частиною суспільства. "За вченням Церкви, сама влада також не має права асболютизувати себе, розширюючи свої межі до повної автономії від Бога та встановленого Ним порядку речей, що може призвести до зловживань владою і навіть до обожнювання володарів" [23].

Отже, виходячи з християнських позицій моралі, свободи людської особистості, слід пригадати минуле уявлення про державу як про непохитний фрундамент авторитарного правління. Важливо говорити про державу як про організатора, арбітра та хранителя закону. Зазначимо, що на державу впливає й Церква, приводячи її до змінень у дусі християнських традицій. Звідси виникає необхідність спеціальних богословських досліджень взаємовідносин Церкви й держави соціальним ученням Церкви за допомогою системного підходу, що єднає політологію та соціальну думки Церкви.

\section{ВИСНОВКИ}

Учені безперервно ведуть дискусії про те, що більш стійке, держава чи суспільство. $Є$ дність поглядів забезпечується лише розумінням того, що державає найважливішим механізмом суспільного розвитку. Згідно з релігійною фрілософією, важливо сказати про те, що сучасне суспільство являє собою динамічне, явище в розвитку, яке чинить прямий вплив і на державу. Реалії сучасного світу, розвиток процесів глобалізації, інформаційних технологій вимагають особливої уваги до реформування держави як нової соціальної системи.

Треба визнати, що процеси державного управління в Україні не завжди ефективно здійснюються за наявності проблем у сорері церковно-державних відносин. Головним чином це стосується різночитання державними службовцями й науковцями понять "світський" та "релігійний" Проведене наукове дослідження підтвердило необхідність вивчення теоретико-методологічних засад державно-управлінських рішень у взаємодії держави та Церкви у контексті релігійної спадщині фрілосоорів та мислителів XX ст. Це має прикладне і практичне значення і розв'язує важливу наукову проблему щодо вироблення цілісної сучасної методології управлінських взаємовідносин держави та релігійних організацій 3 урахуванням цінностей релігії та сучасного секулярного світу.

Аналіз книг релігійних фрілософрів $X X$ ст., присвячених темі державотворення, взаємовідносин держави та Церкви, доводить про пріоритетність релігійної тематики серед інших питань у сорері державного управління. I такий підхід, на нашу думку, видається цілком виправданим, адже мова йде про налагодження більш тісних взаємовідносин між державою та релігійними організаціями. Це стосується пошуку шляхів єднання сучасної науки та релігії. Разом з тим, за наявністю теоретичних підходів у науці державного управлінні взаємодії Церкви та держави, треба визнати, що розв'язання проблеми конструктивного діалогу держави та Церкви у сучасній науці на практичному рівні потребує вирішення на користь не лише держави, а в першу чергу, людини й громадянського суспільства.

На нашу думку, нова концепція управління повинна розглядати систему управління як цілісну духовну й матеріальну систему, яка включає ціннісну систему релігії, фрілософії, систему узгодження інтересів різних релігійних конфесій і соціальних інститутів держави, аналізу, узагальнення та застосування зарубіжного й вітчизняного досвіду державного будівництва у діалозі з релігійними організаціями. Формування цілей управління неможливе без узгодження інтересів релігійних громад і соціальних верств громадянського суспільства. Ідеться про необхідність узгодження інтересів держави, Церкви, політичної еліти й пересічних громадян, державного управління й місцевого самоврядування у сфері релігійного життя українського народу. Таке узгодження дасть змогу визначати стійкий розвиток країни. Важливо підкреслити, що в цьому розумінні необхідний розвиток нової природи держави, яка має об'єднувати різні релігійні організації навколо ідеї державотворення. 
Варто звернути увагу на те, що у релігійній філоcoopiï XX ст. розглядаються докорінні якісні змін у житті держави, яка має стати центром духовного й соціального оздоровлення усього суспільства. На думку релігійних мислителів, необхідна кардинальна зміна регулюючої ролі держави у світі, знаходження державою нової духовної і соціальної стратегії розвитку у світлі одкровення релігії. На думку видатних релігійних філософів, у суспільстві не вистачає об'єднуючих центрів, форм конструктивного діалогу держави та Церкви, загальних громадських обговорень існуючих проблем з залученням представників релігії, літераторів, науковців, митців, людей творчості, тобто всього, що сприяє процесам справжньої інтеграції й духовної консолідації.

\section{Література:}

1. Бердяев Н.А. Диалектика божественного и человеческого / Николай Бердяев; сост. и вступ. ст. В.Н. Калюжного - М.: АСТ; Харьков: Фолио, 2005. - 620 с.

2. Бердяев Н.А. Дух и реальность / Н.А. Бердяев; Вступ. ст. и сост. В.Н. Калюжного. - М.: АСТ; Харьков: Фолио, 2003. - 679 с.

3. Бердяев Н.А. Духовные основы русской революции. Истоки и смысл русского коммунизма / Н. Бердяев. - М.: АСТ, 2006. - 448 с.

4. Бердяев Н.А. О назначении человека. О рабстве и свободе человека / Н. Бердяев. - М.: АСТ, 2006. 637 c.

5. Бердяев Н.А. Падение священного русского царства. Публицистика 1914-1922. - М.: Астрель, 2007. -1179 c.

6. Бердяев Н.А. Философия свободы / Н. Бердяев. - М.: АСТ, 2007. - 699 с.

7. Булгаков С.Н. Два града. Исследование о природе общественных идеалов. - СПб.: РХГИ, 1997. 589 c.

8. Булгаков С.Н. История экономических и социальных учений / С.Н. Булгаков; вступ. статья, сост. и примеч. В.В. Сапова. - М.: Астрель, 2007. - 988 с.

9. Булгаков С.Н.О рынках при капиталистическом производстве. / С.Н. Булгаков; сост., вст. статья и комментарии В.В. Сапова. - М.: Астрель, 2006. - 528 с.

10. Булгаков С.Н. От марксизма к идеализму. Статьи и рецензии / С.Н. Булгаков; сост., вступ. статья и комментарии В.В. Сапова. - М.: Астрель, 2006. $1008 \mathrm{c}$.

11. Булгаков С.Н. Свет невечерний: Созерцания и умозрения. - М.: Республика, 1994. - 415 с.

12. Бычков В.В. Русская теургическая эстетика. М.: Ладомир, 2007. - 743 с.

13. Воденко К.В. История религиозной фрилософии: учебник / К.В. Воденко, С.И. Самыгин. - Ростов н/Д: Феникс, 2015. - 252 с.

14. Замалеев А.Ф. Русская религиозная философия: XI-XX вв. СПб.: Изд. дом С.-Петерб. ун-та, 2007. - 208 с.

15. Зеньковский В. История русской фрилософии. М.: Академический Проект, Раритет, 2001. - 880 с.

16. Катасонов В.Ю. Православное понимание общества. Социология Константина Леонтьева. Историософия Льва Тихомирова / Отв. ред. О.А. Платонов. - М.: Институт русской цивилизации, 2015. - 432 с.
17. Катасонов В. Ю. Русская социологическая мысль на рубеже XIX-XX веков. К. Леонтьев, Л. Тихомиров, В. Соловьев, С. Булгаков, С. Шарапов. / Отв. ред. Н.Н. Бойко. - М.: Родная страна, 2015 - 464 с.

18. Костюк К.Н. История социально-этической мысли в Русской Православной Церкви. - СПб.: Алетейя, 2013. - 448 с.

19. Лосский Н.О. История русской фрилософии / Н.О. Лосский. - М.: Академический Проект, 2007. $551 \mathrm{c}$.

20. Митрофранов Георгий, прот. Россия XX века "Восток Ксеркса" или "Восток Христа". Духовно-исторический феномен коммунизма как предмет критического исследования в русской религиозно-филлософской мысли первой половины XX века. - Ростов-на-Дону: Троицкое слово 2004. - 316 с.

21. Новикова Л.И., Сиземская И.Н. Русская философия истории: Курс лекций. - Изд. 2-е, дополн. - М.: Аспект Пресс, 1999. - 399 с.

22. Огородник И.В., Огородник В.В., Русин М.Ю., Диденко В.Ф. Философрская мысль восточных славян: Библиографический словарь / Науч. ред. Л.В. Губерского. - К.: Парламентское издательство, 1999. - 328 с.

23. Основы социальной концепции Русской Православной Церкви // Русская Православная Церковь. Офрициальный сайт Московского Патриархата [веб-портал] - 2016. - URL: http://www.patriarchia.ru/db/ text /141422.html

24. Солженицын А. На изломах: Рассказы. Крохотки. Публицистика / А.И. Солженицын; Краткие пояснения Н.Д. Солженицыной. - Екатеринбург: У-Фактория, 2007. - 640 c.

25. Сурмин Ю.П. Социология управления: учеб. пособие / Ю.П. Сурмин, И.П. Бидзюра. - К., 2012. $728 \mathrm{c}$.

26. Филипович Л.О. Культура релігійного життя. Вибрані праці. За упорядкування Г. Филиповича і редагування А. Колодного. - К.: УАР, 2016. - 584 с.

27. Франк С.Л. Духовные основы общества. - М.: Республика, 1992. - 511 с. $608 \mathrm{c}$.

28. Франк С.Л. Сочинения. - М.: Правда, 1990. -

29. Франк С.Л. С нами Бог / С.Л. Франк; сост. и предисл. А.С. Филоненко. - М.: АСТ, 2003. - 750 с.

30. Франк С.Л. Свет во тьме. Опыт христианской этики и социальной философиии. - М.: Факториал, 1998. -256 c.

31. Шпидлик Томаш. Русская идея: иное видение человека / Пер. с франц. В.К. Зелинского и Н.Н. Костомаровой. - СПб.: "Издательство Олега Абышко", 2006. -464 c.

\section{References:}

1. Berdyaev, N.A. (2005), Dialektika bozhestvennogo i chelovecheskogo [Dialectics of the divine and human], Folio, Kharkiv, Ukraine.

2. Berdyaev, N.A. (2003), Duh i real'nost' [Spirit and reality], Folio, Kharkiv, Ukraine.

3. Berdyaev, N.A. (2006), Duhovnye osnovy russkoj revoljucii. Istoki i smysl russkogo kommunizma [Spiritual Foundations of the Russian Revolution. The Origins and meaning of Russian Communism], AST, Moscow, Russia. 
4. Berdyaev, N.A. (2006), O naznachenii cheloveka. O rabstve i svobode cheloveka [The Destiny of Man. On Slavery and Human Freedom], AST, Moscow, Russia.

5. Berdyaev, N.A. (2007), Padenie svjashhennogo russkogo carstva [The fall of the sacred Russian kingdom. Publicism 1914-1922], Astrel, Moscow, Russia.

6. Berdyaev, N.A. (2007), Filosofija svobody [Philosophy of Freedom], AST, Moscow, Russia.

7. Bulgakov, S.N. (1997), Dva grada. Issledovanie o prirode obshhestvennyh idealov [Two hailstones. Study on the nature of social ideals], RSHGI, St.Petersburg, Russia.

8. Bulgakov, S.N. (2007), Istorija jekonomicheskih i social'nyh uchenij [History of Economic and Social Studies], Astrel, Moscow, Russia.

9. Bulgakov, S.N. (2006), O rynkah pri kapitalisticheskom proizvodstve [On Markets in Capitalist Production], Astrel, Moscow, Russia.

10. Bulgakov, S.N. (2006), Ot marksizma k idealizmu. Stat'i i recenzii [From Marxism to Idealism. Articles and reviews], Astrel, Moscow, Russia.

11. Bulgakov, S.N. (1994), Svet nevechernij: Sozercanija i umozrenija [Unfading Light: Contemplation and speculation], Respublika, Moscow, Russia.

12. Bychkov, V.V. (2007), Russkaja teurgicheskaja jestetika [Russian theurgical aesthetics], Ladomir, Moscow, Russia.

13. Vodenko, K.V. (2015), Istorija religioznoj filosofii [The History of Religious Philosophy], Phoenix, Rostovon-Don, Russia.

14. Zamaleev, A.F. (2007), Russkaja religioznaja filosofija: XI - XX vv [Russian Religious Philosophy: XI-XX centuries], Publish. House of St. Petersburg University, St.Petersburg, Russia.

15. Zenkovsky, V. (2001), Istorija russkoj filosofii [History of Russian Philosophy], Academic Design, Rarity, Moscow, Russia.

16. Katasonov, V.Y. (2015), Pravoslavnoe ponimanie obshhestva. Sociologija Konstantina Leont'eva. Istoriosofija L'va Tihomirova [Orthodox understanding of society. Sociology of Konstantin Leontiev. The Historiosophy of Lev Tikhomirov], Institute of Russian Civilization, Moscow, Russia.

17. Katasonov, V.Y. (2015), Russkaja sociologicheskaja mysl' na rubezhe XIX-XX vekov. K. Leont'ev, L. Tihomirov, B. Solov'ev, S. Bulgakov, S. Sharapov [Russian sociological thought at the turn of the XIX-XX centuries. K. Leontiev, L. Tikhomirov, V. Soloviev, S. Bulgakov, S. Sharapov], Homeland, Moscow, Russia.

18. Kostyuk, K.N. (2013), Istorija social'no-jeticheskoj mysli v Russkoj Pravoslavnoj Cerkvi [The history of socioethical thought in the Russian Orthodox Church], Aleteeya, St.Petersburg, Russia.

19. Lossky, N.O. (2007), Istorija russkoj filosofii [The History of Russian Philosophy], Academic Project, Moscow, Russia.

20. Mitrofanov, G. (2004), Rossija XX veka - "Vostok Kserksa" ili "Vostok Hrista". Duhovno-istoricheskij fenomen kommunizma kak predmet kriticheskogo issledovanija $v$ russkoj religiozno-filosofskoj mysli pervoj poloviny XX veka [Russia XX century - "East of Xerxes" or "East of Christ". Spiritual-historical phenomenon of communism as a subject of critical research in the Russian religious-philosophical thought of the first half of the $X X$ century], The Trinity Word, Rostov-on-Don, Russia.

21. Novikova, L.I. and Sizemskaya, I.N. (1999), Russkaja filosofija istorii [Russian Philosophy of History], Aspect Press, Moscow, Russia.

22. Ogorodnik, I.V. Ogorodnik, V.V. Rusin, M.Y. and Didenko, V.F. (1999), Filosofskaja mysl' vostochnyh slavjan: Bibliograficheskij slovar' [The Philosophical Thought of Eastern Slavs: Bibliographic Dictionary] Parliamentary Publishing House, Kyiv, Ukraine.

23. Russian Orthodox Church. Official site of the Moscow Patriarchate (2016), "Fundamentals of the social concept of the Russian Orthodox Church", available at: http://www.patriarchia.ru/db/text/141422.html (Accessed 30 Sept 2018).

24. Solzhenitsyn, A.I. (2007), Na izlomah: Rasskazy. Krohotki. Publicistika [On Breaks: Stories. Publicism], UFaktoriya, Yekaterinburg, Russia.

25. Surmin, Y.P. and Bidzura, I.P. (2012), Sociologija upravlenija [Management Sociology], Kyiv, Ukraine.

26. Filippovich, L.A. (2016), Kul'tura religijnogo zhittja. Vibrani praci [Culture of Religious Life. Selected works], UAR, Moscow, Russia.

27. Frank, S.L. (1992), Duhovnye osnovy obshhestva [The spiritual foundations of society], Republic, Moscow, Russia.

28. Franck, S.L. (1990), Sochinenija [Compositions], Pravda, Moscow, Russia.

29. Frank, S.L. (2003), S nami Bog [With Us God], AST, Moscow, Russia.

30. Frank, S.L. (1998), Svet vo t'me. Opyt hristianskoj jetiki i social'noj filosofii [Light in the darkness. Experience of Christian ethics and social philosophy], Factorial, Moscow, Russia.

31. Spidlik, T. (2006), Russkaja ideja: inoe videnie cheloveka [Russian Idea: A Different Man's Vision], Publishing house of Oleg Abyshko, St.Petersburg, Russia. Cтаття надійшла до редакиіï 09.10.2018 p.

\section{wWw. dy.nayka.com.ua}

Електронне фахове видання

\section{ДЕРЖАВНЕЕУУРАВЛПНHЯ удосконалення та розвиток}

\section{Виходить 12 разів на рік}

$$
\begin{aligned}
& \text { Видання включено до переліку } \\
& \text { наукових фахових видань України } \\
& \text { з ДЕРЖАВного уПРАВлІння } \\
& \text { e-mail: economy_2008@ukr.net } \\
& \text { тел.: (044) 223-26-28 } \\
& \text { (044) 458-10-73 }
\end{aligned}
$$

